\title{
Central precocious puberty secondary to hypothalamic hamartoma
}

\author{
CG Tay, MY Jalaludin*, F Harun \\ From 7th APPES Biennial Scientific Meeting \\ Nusa Dua, Bali. 14-17 November 2012
}

\section{Introduction}

Central precocious puberty (CPP) presenting at a very young age is likely to have an underlying pathology. One of the pathologies is hypothalamic hamartoma $(\mathrm{HH})$, a non-neoplastic tumour-like lesion located at the floor of the third ventricle, near the tuber cinereum. Two young children with CPP due to $\mathrm{HH}$ without gelastic seizures or mental retardation were successfully managed and described in this report.

\section{Cases}

Case 1

An 18-months-old girl presented with vaginal bleeding. Physical examination showed breast Tanner stage (TS) 4 with pubic hair TS2. Her follicle-stimulating hormone $(\mathrm{FSH})$, luteinizing hormone $(\mathrm{LH})$ and estradiol were in pubertal range $(6 \mathrm{IU} / \mathrm{L}, 8.9 \mathrm{IU} / \mathrm{L}, 281 \mathrm{pmol} / \mathrm{L}$ respectively) with an advanced bone age of 7 years 10 months. Brain magnetic resonance imaging (MRI) showed a round, non-enhancing, isointense lesion at the tuber cinereum just anterior to the mamillary body representing hypothalamic hamartoma. She responded well with intramuscular $\mathrm{GnRH}$ analogue with resolution of precocious puberty. She is currently 9 years, remains prepubertal with maintenance dose of $\mathrm{GnRH}$ analogue at $4.2 \mathrm{mcg} / \mathrm{kg} /$ day.

\section{Case 2}

A 20-months-old boy presented with rapid growth. Pubertal staging showed gonads TS2 (testicular volumes of 8 mls bilaterally) with pubic hair TS2. His FSH, LH and testosterone were elevated $(12 \mathrm{IU} / \mathrm{L}, 16.5 \mathrm{IU} / \mathrm{L}$ and $12.5 \mathrm{nmol} / \mathrm{L}$ respectively) with an advanced bone age (BA 3 years). His MRI brain confirmed hypothalamic hamartoma. GnRH analogue at conventional dose failed to

Paediatric Endocrine Unit, Department of Paediatrics, Faculty of Medicine, University Malaya, Kuala Lumpur correct the excessive growth and stop the progression of pubertal development until a higher dose at $18.5 \mathrm{mcg} / \mathrm{kg} /$ day was given. He is currently $41 / 2$ years and remains prepubertal.

\section{Conclusion}

CPP secondary to hypothalamic hamartoma usually presents early, before the age of two years. Medical therapy with $\mathrm{GnRH}$ analogue is still the first choice of treatment. The dosage of GnRH varied and in patients whom standard dose showed insufficient effects, high dose is recommended. Surgical intervention is reserved only for those who failed medical therapy or for those with intractable seizures.

Published: 3 October 2013

doi:10.1186/1687-9856-2013-S1-P70

Cite this article as: Tay et al:: Central precocious puberty secondary to hypothalamic hamartoma. International Journal of Pediatric Endocrinology 2013 2013(Suppl 1):P70.

Submit your next manuscript to BioMed Central and take full advantage of:

- Convenient online submission

- Thorough peer review

- No space constraints or color figure charges

- Immediate publication on acceptance

- Inclusion in PubMed, CAS, Scopus and Google Scholar

- Research which is freely available for redistribution 